UDC 371:81

IRSTI 16.21.51

\title{
LEXICAL AND SEMANTIC WAYS OF TRANSMISSION OF EXPRESSION SPATIAL RELATIONS IN THE NOVEL "THE WAY OF ABAY"
}

\author{
Z.ZH. AUKHADIYEVA ${ }^{1}$
}

( ${ }^{1}$ «Almaty Technological University» JSC, Almaty, Kazakhstan)

E-mail: zauresh.59@mail.ru

The given article is devoted to the lexical and semantical peculiarities of the expression of spatial relations in the novel "The Way of Abay". Considering the three-dimensionality (height, length and width) of the category of space, M. Auezov in his epic "The Way of Abay" scrutinizes the transfer of the state of the objective world in a static and dynamic position, also in a vertical, horizontal and volumetric plane with the help of lexical, lexical and morphological and syntactic language units. The results of the research of this work can be used in the preparation of a system of exercises in the preparation of textbooks and teaching aids based on a national-oriented approach to teaching any non-native language, including a foreign one. In this circumstance we see practical significance of the following research.

Key words: category, space, language units, lexical - morphological and syntactic levels.

\section{«АБАЙ ЖОЛЫ» РОМАНЫНДАҒЫ КЕНІСТІК МӘНДІ ҚАТЫНАСТАРДЫН ЛЕКСИКАЛЫҚ ЖӘНЕ СЕМАНТИКАЛЫК ТҰРҒЫДАН БЕРІЛУ ЖОЛДАРЫ}

\author{
3.Ж. АУХАДИЕВА
}

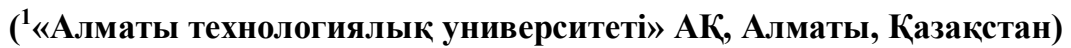

E-mail: zauresh.59@mail.ru

Ұсынылzан мақала "Абай жолы" романында кеңістіктік қатынастарды білдірудің лексикалық және семантикалық ерекшеліктеріне арналzан. Кеңістік категориясының үш өлшемділігін (биіктігі, ұзындыгы және ені) ескере отырып, М. Әуезов өзінің "Абай жсоль" эпопеясында объективті дүние заттарының жаддайын статистикалық жсәне динамикалық жсагдайда, сондай-ақ лексикалық, лексикалық-морфологиялық және синтаксистік деңгейдегі тілдік құралдардың көмегімен тік, көлденең және көлемді жазықтықта беруді қарастырады. Жұмыстың зерттеу нәтижелері кез келген туыстық емес тілді, соның ішінде шетел тілін оқытуда ұлттық-багдарлы тәсілге негізделген окулықтар мен құралдарды дайындау кезінде жсаттыzулар жүйесін құруда пайдаланылуы мүмкін. Бұл жсавдайда осы зерттеудің практикалық маңыздылывын көреміз.

Негізгі сөздер: категория, кеңістік, тілдік бірліктер, лексика, лексикалық-морфологиялық және синтаксистік деңгей.

\section{ЛЕКСИКО- СЕМАНТИЧЕСКИЕ ПУТИ ПЕРЕДАЧИ ВЫРАЖЕНИЯ ПРОСТРАНСТВЕННЫХ ОТНОШЕНИЙ В РОМАНЕ «ПУТЬ АБАЯ»}

\author{
3.Ж. АУХАДИЕВА
}

( ${ }^{1} \mathrm{AO}$ «Алматинский технологический университет», Алматы, Казахстан)

E-mail: zauresh.59@mail.ru

Предлагаемая статья посвящена лексическим и семантическим особенностям выражения пространственных отночений в романе «Путь Абая». Учитывая трехмерность 
(высоту, длину и иироту) категории пространства, М. Ауэзов в своей эпопее "Путь Абая" рассматривает передачу состояния предметов объективного мира в статическом и динамическом положении, также в вертикальной, горизонтальной и объемной плоскостях при помощи лексических, лексико-морфологических и синтаксических языковых средств. Результаты исследования работы могут быть использованы при составлении системы упражнений при подготовке учебников и пособий, основанных на национально-ориентированном подходе к обучению любому неродному языку в том числе и иностранному. В данном обстоятельстве мы видим практическую значимость данного исследования.

Ключевые слова: категория, пространство, языковые единицы, лексико - морфологический и синтаксический уровени.

\section{Introduction}

The given article is devoted to the 175th anniversary of the great poet, philosopher, translator and composer Abay Kunanbayev.

The epic of "The Way of Abay" written by the great writer of the twentieth century $\mathrm{M}$. Auezov is translated into several languages of the world, including Russian, English, Bulgarian, Hungarian, Vietnamese, German and Greek, Korean, Polish, Romanian, Slovak, Turkish and French, Czech, Persian and Hindi languages which has shown the spiritual wealth and great culture of Kazakh people. The whole world recognized writer M. Auezov's epos " The Way of Abay" is written in a imaginative language that expresses a variety of colors and emotions. We see the epiphany language's subtlety, beauty, rich colors in the frequent use of linguistic units that represent spatial relationships because the human, animal and the whole world live in a space that belongs to one of the forms of objectivity of matter.

Nothing happens without the space and can not be. Let's analyze from the point of view of philosophy. What is the connection between philosophy and linguistics? Then, what is "space"? Space category means simultaneous arrangement of objects, bodies, actions and phenomena. This particular order is itself a structural element that represents spatial relations [3].

As is known, all the diversity of spatial relations in objective activity is reflected through human thinking. Logic-philosophical analysis plays a major role in the study of spatial relations. All cognitive activities of the organization, which are aimed at studying objective validity, are carried out in the form of logical categories. "Logical categories retain their independent meaning and establish the connection of language with thinking, transmitting the logical content of the grammatical construction formed in the language." $[4,9]$

\section{Objects and methods of research}

Objects of the research are words, phrases, and sentences that express spatial relationships. In considering the features of the expression of spatial relations in two different languages were used a complex comparative method and a distributive analysis. A distributive method of linguistic research, in which the classification of language units and the study of their properties are made solely on the basis of the distribution of the units in question in the speech stream, i.e., on the basis of their compatibility with other units in linguistics.

\section{Results and discussion}

Taking into account three dimensional / height, length and width of the earth, M. Auezov passes through the lexical, lexical- morphological and syntax linguistic units of the three-level level in the normal / statistical / dynamic state / dynamic / vertical plane, horizontal plane and volumetric logic of the objects of objective world in the epic of "The Way of Abay ". For example: "Bakanas, Baikoshkar are the largest rivers in this region. The two ends of the glaciers in the outskirts of Shyngys. However, Kunanbay villages were previously inhabited by Baikoshkar and the Bakanas River belonged to Koksha ". In these examples river and sea symbolize the water spaces, while the word jaylau indicates a part of the open space in the horizontal plane. The village names the location of the inhabitants. For example: "Abay is sitting looking at Shyngys through the window kneeling and putting his elbows on the windowsill and his chin on his hands. In addition, on the right there is Zere who has a baby on a bed. The words in the sentences such as the doors of houses, parts of buildings, elbows, hands signify the name of the person's body parts, the bedding is the name of the household items and again expresses the peculiarities of the philosophical space. Based on these examples this space can be subdivided into meaningful nouns, semantics as they are complementary. In defining the spatial relations 
that textually permeate the entire semantic structure of language, we must first describe the role of spatial peculiarity, which we refer to the extent and order of objects in space. The practical activity of man begins with the comprehension of space. The child who begins to learn the real world, first of all gets an idea of the spatial properties of reality. It is established that the first interrogative words "wherewhat" /locative-object relations/ the child determines, masters at the very initial stage of mas-tering the native language much earlier than the causaltemporal "when-why" / temporal-causal relations.

Depending on semantic peculiarities the nouns that belong to lexical units can be classified into smaller groups such as the names of body parts and household names, body names, names of water concepts, names of open spaces and locations. Accordingly, nouns in smaller groups can be subdivided into the following large groups, depending on which spatial expression or representation $[1,15]$

1. Water space

2. Earth space

3. Air space

4. Universe space

Thus, all the nouns belonging to the lexical units associated with water, land, air and space are presented in M. Auezov's epic "The Way of Abay". Taking into account the three-dimensional nature of space we will distinguish between objective objects in horizontal plane, vertical plane, and closed-loop space in the novel.

The majesty of Kazakh language was given by $M$. Auezov through different excellence units of spatial. Among these linguistic units there are the auxiliary names used in the form of cases. For example: "In front of the stranger Shyngys lies horizontally. All of them brought two horsemen to the tomb of Kutzhan and wept than buried with dignity. All the coworkers cried and cried over this cemetery. All six of the houses near the winter were fired and the horsemen crawled and threw them into a whip. There are several names outside the house that are rattling, jumping fast and fasting their names."

In all these examples in front of the migration, near the grave, on the ceiling, near the outside of the house, these examples are used as auxiliary names, not in the head, in front of them, beside them, and their meanings which have their lexical meaning. Accordingly, all of these words are not individual members in the sentence but additional space to the meanings of their earlier names. The auxiliary names are few in number, such as head, front, back, abdomen, skin, face and cheeks. If two point spacing on a horizontal plane is expressed as a real boundary, the auxiliary names that are associated with the title may sometimes coincide with the different greases.

A huge role in the expression of static spatial relations is played auxiliary names and postpositions. Auxiliary names can be used in two functions: 1) as independent words, representing the names of the parts that are common to all objects and retaining their lexical meaning, e. g.: "inside, middle, front".

2) As auxiliary words, they refine and supplement the spatial meaning of the dependent word in the function of reference point e.g. "Inside the room near the house, behind the barn".

The expression of static spatial relations is also realized by nouns in the local case, which do not need detailed concretization of parts of reference point such as surface, volume, etc.

For example: "The road from Karkaraly to Shyngys is long ...". The preceding example in this example recalls a local value pointing to the extra distance from Karkaraly to the word "Shyngys". That is the name they are combining is a small contribution to the basic meanings of words.

Static spatial relations by the location of the object relative to the front part (facade) of the reference point are expressed by means of the auxiliary name "in front" in the local case, combined with the nouns of the subject meaning of the genitive case. For example: "On the way back i saw a cart in front of Bapai's door".

In the role of volume objects can be, as well as animate objects, i.e. a person or group of people or animals. For example: "Before Qodar there are a lot of people. Chauhan waved his hand in front of the folk".

The expression of the meaning of the object's location between two reference points is implemented by means of the auxiliary names "between, middle, among" in the local case in combination with those existing in the genitive case. These auxiliary names have a similar meaning, but nevertheless distinguish between them. The difference between them is that «between" is used with words denoting individual, specific objects (two or more), the auxiliary name is used with words denoting one closed object or a set of several objects, including the collective words "people, crowd". For example: In the middle of crowd was Malbasar. 
In Kazakh language location of many things which are in different types of landscape such earth's, air and water spaces that are used as orientations, are transmitted with the help of the isaphic combination of the auxiliary name "in, on, inside". For example, "There were ten people inside the house."

Contact location of the oriented things is transferred by the auxiliary names: surface, cheek, head, face. "On the side of the horse there were traces of which strap. Kulunshak was sitting on the top of the hill."

Thus, the location of any object or phenomenon in space in Kazakh language can be expressed through interaction with other elements, and in the first place, taking into account the semantics of the corresponding verbs associated with them. This circumstance makes it possible to express a virtually infinite number of real types of spatial relations.

Auxiliary names play a great role in representing space-based relationships. Assistive names sometimes act individually on the part of other keywords. For example: "Kunanbay and Izgut are coming to Backyard villages. There was Semipalatinsk on the horizon, on the bluish tower". In this example, the words on the left, the back, the left are the addresses in the clause indicating that the object is located in front or behind, left and right. Occasionally it is highly valued that the front and rear positioning of objects can be determined by step, kilometers or different national measurement units. The length of human body or available material were measured to measure height, length, distance and depth.

For example: Abay was in the lead. In this example the axis length is $1,0-1,5 \mathrm{~m}$ in length. The lake was visible from the street. The word "goat" means "nearest distance" and such comparable comparisons not only increase the value of the work but also encourage the reader to read again and make the novel attractive for readers.

Here are some of the lexical, lexicalmorphological linguistic units expressing these minimal values. M. Auezov frequently used his own examples. A lot of questions about why he did not write the Epiphany "The Way of Abay" in Russian Auezov replied: "I couldn't write my novel in Russian". At that time, my production of a similar voice, as soon as possible, would translate into another language, meaning that it should be restored to fullness of national color. This is the first and the last and as a matter of fact, the creativity of the creator of the word itself is a way to formulate the image of other person, so long as it is possible to formulate a picture of life with the beauty of the native language" $[2,3]$.

\section{Conclusion}

Finally, when we look at the linguistic aspect of the space category it is characterized by the set of linguistic units. The realization of the human thought depends on the different languages differing from one another in phonetic and grammatical structures.

The structural and semantic analysis of the lexical and grammatical means of locality in Kazakh language using examples from the novel of the outstanding writer M. Auezov "The Way of Abay" made it possible to determine various types of location in space of some objects relative to others.

The emergence and formation of the national measurement units are primarily due to the need for such things as comparison of different objects such as livestock, migration, and addressing in the daily lives of population.

Forms of logical thinking are not the same as grammatical categories but in spite of differences there is a special relationship between them which provides logical content in conversation. Dialectical and philosophical connections between nature and man, society and man are considered in the novel "The Way of Abay" in a comprehensive and profound sense.

The above examples show that the average frequency of language units expressing static spatial relationships is different. Nouns with a specific spatial meaning have the highest frequencies.

Taking an important place in the formation of any statements, case-nominal combinations with local semantics are defined as lexicalmorphological and syntactic constructions that express the largest number of aspects of the category of space in Kazakh language.

\section{REFERENCES}

1. Aukhadieva Z.Zh. Spatial relations in German and Kazakh: Dissertation for the degree of Doctor of PhD: 10.02.04 German languages, 10.02.02 Modern Kazakh language. - Almaty, 1996.- 192 p [in Russian]

2. A. Sairanbaev. M. Auezov about Abay. The newspaper "Almaty Akshamy". 26.09.2011. p3. [in Kazakh]

3. Akhundov M. D. Concepts of space and time. Moscow: Nauka, 1982. - p.221 [in Russian]

4. Meshchaninov I. Y. Correlation of logical and grammatical categories / / Language and thinking. Moscow: Nauka, 1967. - p. 1. [in Russian] 